\title{
GEOPOLITICS OF VACCINES: WAR BY OTHER MEANS?
}

\author{
Biljana Vankovska ${ }^{14}$, \\ Faculty of Philosophy, Ss. Cyril and Methodius University
}

\begin{abstract}
The article sheds light on the causes, consequences, and possible scenarios of the geopolitics of vaccines. Given the international context and domination of structural violence and clashes of great powers on the global faultlines, no wonder that the vaccines have turned into a power politics tool rather than a global public good and an asset to save lives. Furthermore, private corporations have strengthened their grip on the states and their populations, while the state leaderships of the rich countries ride on the wave of vaccine nationalism and overt discrimination of others. The issue of quality, availability, and distribution of anti-Covid-19 vaccines just offers a glimpse into an apocalyptic future - unless something is done soon to re-shape both State and the world order. The research sources are media-based, but from a variety of geographical areas. Also, they are correlated with available academic analyses and findings concerning the so-called pandemopolitics, i.e. international and state politics in the time of pandemic.
\end{abstract}

Keywords: geopolitics, vaccines, covid-19, power relations, capitalism, State.

\section{Introduction}

Traditionally, geopolitics is understood as an analysis of the geographic influences on power relationships in international relations. At one point it seemed as if its relevance was fading away, both due to the balance of fear due to the nuclear weapons possession but also because of the enthusiasm and hopes invested in the prophesied "end of history". Allegedly globalization (a term with a different meaning but one that has absorbed in itself the uglier and more honest concept of economic neoliberalism) worked against any analysis that would take into account borders and political-territorial spheres. However, it did not take long to dismantle the "end of history" as a pipe dream (or an obscure hegemonic geopolitical agenda).

In contemporary discourse, geopolitics has been widely employed as a loose synonym for international politics, i.e. for the arena that is influenced by a vast number of different factors that go beyond geography. For quite some time, the use of geopolitical lenses in various contexts witnesses a re-birth and revival: it implies a new dynamic of the changing international order with no unanimously accepted definition. Some analysts have come out with interesting proposals, such as naming it a second global bipolarity and/or bi-multipolarity (Kirkova 2015). In 2003, the US National Security Advisor Condoleezza Rice stated that multipolarity was never a unifying vision, but a necessary evil. In her words, multipolarity is a theory of rivalry or competing interests, and at its worst, competing values (Financial Times, 19 December 2003). Of course, it was a position of the only remaining superpower that aspired to sustain its global hegemony (the so-called unipolar moment). Frank Umbach

${ }^{14}$ Contact address: biljanav@fzf.ukim.edu.mk 
(2006) argues that although there is no general agreement on what multipolarity exactly is, it is generally assumed to mean that there exist diverse poles that are equal in their political weight and justification. Polarity is not only a matter of distribution of power, it is also a matter of the interests of the states in power distribution (Kegley and Blanton 2012). The last decade showed a few shifting (informal) coalitions among the three great powers (USA, China, and Russia) and the other major powers (such as Germany, Great Britain, France, Brazil, India, etc.), let alone the smaller states rotating as satellites around each of them. The current line between potential 'friends and foes' is not strictly defined and unchangeable: state leadership usually leads to pragmatic politics depending on the cost-benefit analysis of their own national interests. Fouskas and Roy-Mukherjee $(2019,967)$ rightly point out that "global politics can no longer be premised on the binary Schmittian divide of 'friend-enemy', as was the case during the Cold War ('us against Communism') and after 9/11 ('us against the terrorists') - domestic politics is a different ballgame."

On the other hand, while the theoretical and empirical analyses of the international order are ongoing, there is also a one that determines not only global relations but humanity's existence. Varoufakis' diagnosis of emerging techno-feudalism refers to the growing power of private/multinational corporations (not only in the pharmaceutic sphere) which are now able to impose their powers even on the great (state) powers (Al Jazeera 2021). Combined jointly, the profit and the will to power (to use Nietzsche's phrase), under the special circumstances imposed by the imperatives of the risk society in a pandemic, have produced the terrifying result of a world divided into territorial units that echo Donald Trump's motto "America First", which now often reads Germany first, or any other major state's name "first". In other words, the globalization mantra has withered away under the pressure of the so-called vaccine nationalism (and slef-interest).

\section{The State's Comeback: A Good or Bad News?}

The State has always been a peculiar entity: on one side turned towards the selfish interests of the ruling elites, and on the other - providing and caring for public interests. The "Janus-faced" characteristics are also explained as a situation in which the State may apparently put the public interest in its focus, but on the other hand, it may (mis)use an extreme amount of resources for programs that do not benefit society and/or the country in the long run. It is all about the dialectic unity of the two sides of the state's functions where the façade of the public and good things done for the sake of the people provides wide legitimacy for all its actions, including the ones that go against such promises. For years, even the most developed Western states have eroded and compromised the idea of a welfare state due to the global impact of neoliberal medicines of the 70s. In a nationally televised 2013 annual address, the Dutch king, Willem-Alexander, declared that "the welfare state of the 20th century is over" and a new "participation society" would take its place, in which people must save and invest to create their own social safety net with less help from the government (Independent, 17 September 2013).

It seems as if the State has now revamped its old mission defined as res publica due to the emergency reasons, and thus it has distanced itself from the 'minimal state' version for the sake of the market's invisible hand. The so-called 'participation society' has proved unable to deal with a health crisis of such proportions and specific scientific and 
medical requirements. However, the wake-up call of the Covid-19 in spring 2020, when it finally reached the EU states, was not gentle at all. It was Margaret Thatcher that advocated a reduction of social institutions because they were "too costly". Even the EU states that have not totally given up the welfare state policy have now faced the consequences of the disastrous economic logic applied to social services, primarily health care. Many state leaderships that were proud of the high living standards have discovered that their health systems had been so exposed to austerity measures and profit-based logic that they were unable to respond adequately. Having been unable to change things amidst the havoc, they have resorted to other measures, such as lockdowns, disciplining the masses, fear mongering, and even stigmatization and punishment for the disobedient ones. The bio-political power for the sake of life is in the hands of the state authorities, but the medical protection (be it in a form of medical equipment, research, therapy, and/or vaccines) is merely out of state control - except in the states (such as China and Russia) where the market is not as 'free' as it should be according to the neo-liberal paradigm.

A more insightful analysis, however, shows that there is de facto nothing new under the Sun: even in the countries led by the most ardent advocates of economic neoliberalism, there has always been a hidden attachment between corporate capital and state guarantees - even since the Great Deal, or the bail-out operations after the 2008 global financial crisis. In this respect, the ordoliberal version of the "social market economy" (advocated by Germany, and by its direct influence in the EU) has been more honest (Fouskas and Roy-Mukherjee 2019). Without state support (and public money) the financial sector could not have got out of the deep crisis imposed by bubble financialization. Centuries ago, John Locke and Jean Jacques Rousseau, agreed (although from different ideological positions and with contrasting attitudes towards private property) that the State is but a body for property preservation.

The falsehood of the proposition that the line of demarcation between capitalism and socialism is the State's (non)involvement in the economic and financial sphere (but also in citizens' privacy) becomes most evident during a time of crisis. The (democratic) State needs legitimate grounds for any intervention in these 'free realms' - be the reasons moral, humanitarian, or social. The key issue is the moment of the start and the end of the state intervention since there is an empirically proven case that the state apparatus would not easily give up already gained expanded functions. It is more likely that there will follow a vast array of newly invented reasons for the extension of the state of emergency, while the weakened society that is still recovering does not possess enough strength to resist. The state form is not a crucial factor here: both democracies and non-democracies may embrace interventionist measures. Capitalism is quite possible without democracy, as history teaches. In certain historical situations, it is a democratic state that saves capitalism through damage control and by use of means that only the State possesses.

The pandemic has once again proved that state policies assure that more resources flow to the rich rather than to the needy. Ruchir Sharma (2020) rightly argues:

"Modern society looks increasingly to government for protection from major crises, whether recessions, public-health disasters or, as now, a painful combination of both. Such rescues have their place, and few would deny that the Covid-19 pandemic called for dramatic intervention. But there is a downside to this reflex to intervene, which has become more automatic over 
the past four decades. Our growing intolerance for economic risk and loss is undermining the natural resilience of capitalism and now threatens its very survival. The world economy went into this pandemic vulnerable to another financial crisis precisely because it had already become so fragile, so heavily dependent on constant government help."

"Socialism for the rich and capitalism for the rest" - a variation on a theme popularized in the $1960 \mathrm{~s}$ - applies when the government intervention does more to stimulate the financial markets than the real economy. Despite all the critical tones and promises that "once the pandemic is over, we all need to talk", there is still a major concern about how to save and beautify the capitalist system and thus hide the structural violence embedded in it. A recent $0 x f a m$ study (2021) found that since the start of the coronavirus pandemic, the world's richest 10 billionaires have seen a wealth increase of half a trillion dollars - enough to pay for every person on the planet to get a vaccine.

According to some authors, the Covid-19 pandemic seems to confirm that glocalism, a phenomenon that theorizes a close correlation between the sphere of the local and the global, is now the new normal. Terranova $(2020$, p. 515) argues that the rapid spread of the virus seems to show how the international order, focused on borders and political-territorial spheres, is currently struggling to manage complex problems caused by factors such as innovation and the mobility of people, goods, and information. However, our key concern in this paper is the production, distribution, and effects of the anti-Covid-19 vaccines.

\section{Vaccines (Dis)Order: Geopolitical Competition vs Health Protection?}

At the outbreak of the pandemic, all relevant organizations and authorities used to talk about an "invisible enemy". With no intention to go deeper into the issue of the virus' real origin (Boyle 2020), it seems appropriate to agree that the notion of pandemopolitics may help understand how a public health problem becomes a geopolitical and geo-economic issue (Viorel et al, 2020).Like in any war, here too truth was the first victim: China was almost immediately blamed by the Trump administration as the main culprit for the origin and the spread of the disease. In other words, great powers acted and positioned themselves internationally in the face of the pandemic in a strongly geopolitical way along areas of divergence which had persisted for a long time.

The country of the alleged origin of the pandemic quickly imposed censorship on academic and research findings, while across the ocean there was hate speech about the "Chinese virus" by the US top leadership. President Trump said the coronavirus pandemic was a bigger "attack" on the United States than the one on Pearl Harbor and the World Trade Center in 2001 (BBC News, May 7, 2020). The rare critical voices from the West that identified non-Chinese origins of the pandemic were also either 'canceled' or downplayed (it was the case with Prof. Francis A. Boyle, for instance). Western academia opened the doors of the most prestigious academic journals for any contribution on this topic, often at the expense of accuracy and quality. Every finding or written assumption was put on a fast-track procedure, even without a proper peer review, so the number of scientific findings created real cacophony and did not necessarily help the fight against the Covid-19 pandemic. According to scientists for other disciplines, there has been a lot of academic profiteering thanks to the 
Covid-19 interest prevalence. Also, the world of academia and research centers mirrored the behavior of their states or political/ideological alliances. Instead of universal solidarity and cooperation in fighting the invisible 'enemy', researchers have continued their (personal and institutional) race in terms of numbers of publications, grants, and projects.

In spring 2020 one state after another were undertaking measures that had been heavily criticized in the time when Wuhan was the center of attention. The lockdowns and various means of intrusion into people's intimacy and privacy have become commonplace. The rise of national state responsibility and the state borders re-appeared even within the EU. The growing and urgent needs for medical equipment (including masks and disinfectants, let alone respirators) quickly exposed the fractures of the EU's alleged solidarity and even the competency of the EU institutions. Only when China, Russia, and Cuba appeared as leading powers in the so-called 'mask diplomacy' with Italy as one of the first recipient countries, did the West see the geopolitical danger, but in a different field.

The road to vaccines has not differed much. But what preceded was the West's awareness of its own vulnerability in the pharmaceutical field. For instance, according to media reports, with over $80 \%$ of medicines produced in Asia, France has been dependent on the Asian states, which was noted by the state leadership. The pandemopolitics called for a new marriage of interest between pharmaceutical companies and politicians in the risk society. The issue of having control over 'national' pharmaceutical capacities (but also some others, such as food production) was seen as an issue related to national sovereignty and society's resilience and sustainability. As said in the French media (France 24, 13 May 2020) "a shortage of masks, gloves, swabs... and now health has become a matter of sovereignty and national security". The same messages have been sent from the capitals of many European countries.

While promoting the idea that the pandemic was not only a global health issue but rather a geopolitical and geo-economic one, some scholars explicitly joined the blame game by pointing out China's alleged aggression. They argue that "humanity has entered a new geopolitical cycle in which China's centrality cannot be ignored", i.e. that the multipolar world would be increasingly dominated by China, who will not be shy to use all geopolitical and geo-economic levers to discourage its competitors (Viorel et al, ibid.). This position echoes that of NATO: China has been identified as a key danger for the Alliance in the coming period, in addition to Russia. In fact, the latest expert report entitled NATO 2030: United for a New Era (2020) argues for a more determined position by NATO, while the enemies are directly pointed out (Russia and China). The report shows that the world is projected as a global battlefield, while NATO's response to its irrelevance is more NATO, i.e. a strengthened and enlarged Alliance (Vankovska 2020, 77). Even if the world is not bipolar any longer, such a posture makes NATO's rivals reluctant to envisage any closer cooperation on a political, but also on any other level. Actually, the geopolitical games have continued like business as usual even in the face of humanitarian catastrophes. For instance, Iran suffered a great loss due to the pandemic under simultaneous sanctions. In sum it was restricted to provide the essential basic medical equipment for diagnosis, treatment and prevention of the COVID-19 thanks to the United States political and economic sanctions that compromised country's health system. (Abdoli 2020).

At first, the leading world scientists were cautious and warned the public that much time and a lot of effort were needed to find a good and secure vaccine, let alone production and distribution. A process that used to take a few years, all a sudden obtained a dimension 
of geopolitical urgency and it became a matter of international prestige. The corporate media have had their role in the creation of the overall atmosphere of the vaccine race on a global level. Russia was the first country to register a COVID-19 vaccine (Sputnik V) in August 2020 (Deutsche Welle, 11 August 2020). It was followed by Pheizer and others. Instead of relief and joy over the discovery, the media fueled distrust that came close to a conspiracy theory - as if it was not enough that the world population had already been exposed to numerous paranoiac versions of the "real goals" behind the mass vaccination process.

As we speak, there are seven vaccines approved for full usage, six authorized for limited use, 23 in phase 3 development with large-scale efficacy tests, and more than 80 in phase 1 or 2. At least nine different technology platforms are under research and development to create an effective vaccine against COVID-19. It is worth mentioning that there was already some knowledge and experience with the SARS and MERS viruses and vaccines, so the entire endeavor did not need to start from zero. WHO officials stress the unprecedented amount of financial means invested in vaccine development and cooperation as a key factor for relatively swift results. The media agreed: the Covid-19 crisis caused a huge impact that resulted in the highest allocation of money ever recorded in world history in trying to find a vaccine (NEU, 9 January 2021). However, one can hardly disregard competitiveness, secretive efforts, and the lack of wider global cooperation, which speaks volumes about the state of affairs when it comes to humanity. WHO's official stand is that: "it's not vaccines that will stop the pandemic, it's vaccination, we must ensure fair and equitable access to vaccines, and ensure every country receives them and can roll them out to protect their people, starting with the most vulnerable". However, in May 2021, the facts showed this picture: 160 million people had been fully vaccinated according to OWD (University of $0 x$ ford), i.e. $2 \%$ of the world population, out of which $60 \%$ are living in the US or the European Union, which account for less than $10 \%$ of the world population (Amundi Research, 2021).

Graphic 1: Vaccination process in the world regions

\section{1/ Uneven vaccination among regions}

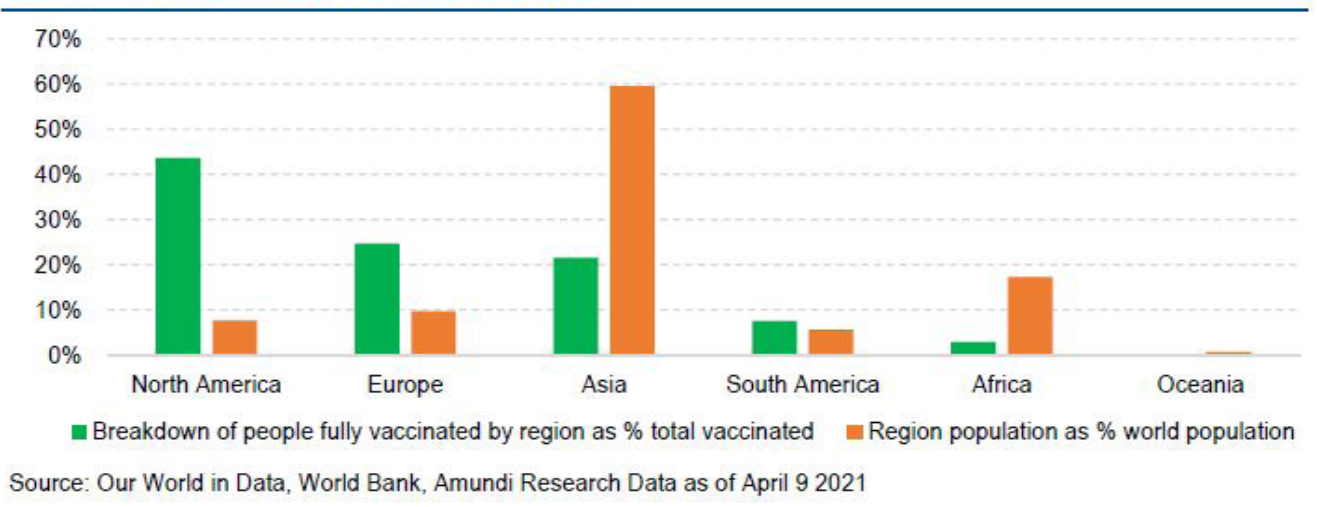

As of the end of September 2021, 6.18 billion doses of COVID-19 vaccines have been administered worldwide based on official reports from national public health agencies. (Our World in Data 2021). According to the same sources, $45.2 \%$ of the world population has received at least one dose of a COVID-19 vaccine, and only $2.3 \%$ of people in low-income 
countries have received at least one dose (See Graphic 1). The pandemic of inequality can be easily seen in this instance as anywhere else.

\title{
Vaccines as Global Public Good
}

In May 2020, a Financial Times editor Pilling wrote the following seemingly prophetic words (2020):

\begin{abstract}
"Imagine if, in a year's time, 300m doses of a safe and effective Covid-19 vaccine have been manufactured in Donald Trump's America, Xi Jinping's China or Boris Johnson's Britain. Who is going to get them? What are the chances that a nurse in India, or a doctor in Brazil, let alone a bus driver in Nigeria or a diabetic in Tanzania, will be given priority? The answer must be virtually nil."
\end{abstract}

A few months later, Politico (27 July 2020) rightly spoke of the ultimate geopolitical game of vaccine distribution: "Who will get the coronavirus vaccine first? All the lofty rhetoric aside, geopolitics and money talk. It's not purely about protecting a population's health". As many experts see it, a vaccine is also vital in getting economies back on track. In the first months of 2021, the Financial Times editor's assumption proved wrong on only one account: not only USA (in cooperation with Germany), China, and Great Britain (in cooperation with India) licensed their vaccines, but in addition to Russia there were many other producers, such as Cuba, for instance. Some smaller states appear on the scene with their manufacturing facilities aimed to produce vaccines as subcontractors/hubs. For instance, Belorussia and Serbia come to mind, thanks to their close relations with Russia and China. Hence the vaccine's release in Belorussia is expected to fully meet the country's need for a vaccine against coronavirus (Precision Vaccinations, 27 February 2021; Xinhua, July 2021; TASS, September 2021). Serbia, on the other hand, is to become a vaccine production hub for the Western Balkans and beyond (Intellinews, 17 February 2021). In June 2021 it started production of Sputnik V vaccine (Euractiv, June 2021), and as of September 2021 the Sinopharm vaccine factory has started working (Balkan Insight, September 2021). Pilling proved right in terms of the lack of solidarity and fair distribution of the vaccines, even within the societies who were lucky to have them. On a global scale, solidarity is closer to science fiction than a realistic scenario. Probably, the most discouraging example is the European Union itself.

However, there are precedents too. The principle of access to medicines was established with the HIV-Aids pandemic, in which life-saving medicines were originally priced far above the means of patients in Africa and other parts of the developing world (Financial Times, ibid.). But, in its 2001 Doha Declaration on Trade-Related Aspects of Intellectual Property Rights, the World Trade Organization made it clear that governments could override patents in public health emergencies. As a result, a tiered pricing system has developed in which drug companies make profits in richer countries while allowing medicines to be sold more cheaply in poorer ones. This time global solidarity is tested not only vis-à-vis pricing the vaccines but also in terms of their availability. The smaller and weaker states could hardly get a fair share of the vaccines. They are rather pawns in the geopolitical games in which major 
producers give 'vaccine packages' in a pompous way, through ceremonies and in front of cameras, to promote their alleged solidarity and closeness to one or another country/region.

A global alliance known as COVAX has been established to accelerate the development and manufacturing of COVID-19 vaccines and ensure that there is fair and equitable access to these vaccines for all countries (WHO Newsroom, 28 October 2020). The idea was to prevent a repeat of the mad dash in 2009 to secure the swine flu vaccine, which resulted in highincome countries commandeering the lion's share, leaving poorer countries far down the queue. Interestingly, unlike the USA, China has joined COVAX. There is de facto no alliance so states are trying to find their own way (or better, a short-cut) to vaccines even if it means bypassing agreed rules among the allies (which is the case with the EU). More and more countries are seeking to establish direct ties with the pharmaceutical companies and thus avoiding bureaucratic and other hurdles that govern the Union. Two contrasting examples come to mind concerning the EU member states. On one hand, the Croatian president gave a rather resolute statement for a TV interview: "This is not about sovereignism but about loyalty to the citizens. I would have bought vaccines even from the Chechen mafia, if available. That's right, I'm caricaturing. Of course, Russia does not have enough. But this concerns my citizens, and who asks Brussels... Just like with the migrants, one should work based on one's own interests. We need vaccines now." (Dnevnik.hr, 18 February 2021) On the other hand, the Bulgarian parliament rejected the proposal of the largest opposition party for the government to start negotiating the delivery of the Russian vaccine. The official statement read that the government would take "all necessary steps to consult the European Commission in a timely manner and explore the possibility of purchasing vaccines that have been authorized in nonEU countries and the European Economic Area" (Novinite, 5 March 2021).

The Macedonian case is illustrative too: the new NATO member state (as of March 2020) has been wavering between its commitment and loyalty to the West at any cost, including the health of its population, and the public pressure for better health protection and vaccines. Quite naively, in Match 2020 even the mainstream media spread the narrative that NATO (and hopefully, the EU) would assist the country's health system. In an interview for a pro-government TV channel, the NATO Secretary-General put it bluntly that the Alliance was there to provide a security umbrella for its new member but it should not expect anything else, or more palpable. As the crisis was worsening, NATO assisted in a peculiar way: by sending blankets and 16 respirators. The latter was proudly stressed by the US Ambassador to Skopje in a TV interview in February 2021. The EU was a much bigger disappointment not only to the Macedonian public but for the entire Western Balkan region. In the meantime, the Macedonian authorities who relied on Brussels, but also on the newly established friendships with the EU neighbors, Greece and Bulgaria, had rejected an early offer from Moscow. Paradoxically, the first vaccines (even in a rather symbolic number) were delivered by a non-NATO neighbor Serbia and by the new 'archetypal' enemy - Russia. The receipt of the "Serbian vaccines" raised eyebrows in Sofia, whose government immediately blamed Belgrade for political and identity meddling into Macedonian affairs - and promised to offer a number of vaccines mainly for its own (Bulgarian) minority in Macedonia. However, the 'Bulgarian' vaccines (of Western origin) arrived in September 2021, just days before expiration of date of use. Even more irony of destiny is the fact that the biggest number of vaccines rolled out in the country are from China - i.e. the biggest number of citizens is vaccinated with the Chinese Sinovac vaccine. 
To sum up, vaccines are not only a matter of global geopolitical rivalries but create similar effects on a regional level and even tackle identity conflicts among the Balkan neighbors. From a wider point of view, it is interesting to point out that Macedonia and Ukraine, two countries that went through colored revolutions/regime change inspired from the West, seem to be forgotten and left in the lurch - having been caught out in the geopolitical race for Covid vaccines their leaderships lament that their allies have forgotten them already (New York Times, 9 January 2021). Macedonian Prime Minister explicitly said that he had talked first with the Western allies to ask for understanding - and got it. In his words, the US and NATO understand that we have to buy vaccines from China (СДК, 3 February 2021). The Western partners did not totally forget its Macedonian partners: "when there is no Pfizer, there is Schmeisser. A US donation of 1,269 M4 automatic rifles for the Army of the Republic of Macedonia is set to arrive in the country today", reported the media (Republika, 1 March 2021).

To the great surprise of many, Serbia appeared as one of the most successful states in providing vaccines even beyond the region. The surplus of vaccines allowed even the nonpopular president Vučić to play the card of vaccine diplomacy and thus increase the country's soft power in its once hostile neighborhood and far beyond within the non-alligned countries' club. Serbia shared small portions of its vaccines in Macedonia, Montenegro, and Bosnia and Herzegovina - a move that has cynically been dubbed "vaccine tourism". The latter's foreign minister openly expressed her dissatisfaction with Serbia's assistance even blaming Vučićs donation for being of low quality (i.e. the vaccines were of Indian production) and were usually used in poor countries (Buka 2 March 2021). In the otherwise divided Bosnian society, this statement was met with strong criticism on behalf of the incompetent and arrogant minister who believed that Bosnia was not a poor state. The loyal pro-Western activists and analysts from the Balkans were immediately alarmed about the shift towards the East (Russia and China) as something that was more threatening than the virus itself (for instance, RFE, 16 February 2021; CHOICE 18 February 2021). They also did not fail to stress Vučić's populism (Bloomberg, 22 January 2021), which might be true - yet it was an example of a multilateral foreign policy of a militarily neutral state from the Balkans.

Global South, forsaken and forgotten as ever, has tried to find an "African solution for African problems". In June 2020 Madagascar's education minister planned to give students sweets to take the bitter edge off an herbal tonic called Covid Organics that the government had been distributing as alleged prevention and cure for COVID-19. Despite the WHO warnings, orders for Covid Organics quickly came from Liberia, Nigeria, Guinea Bissau, Equatorial Guinea, Senegal, and others (Deutsche Welle, 15 July 2020). Addressing world leaders during de 76th UN General Assembly, Ghana president described the move by some Europeans who fail to recognize vaccinations manufactured in India as "retrogressive", and blamed Europe for use of Covid-19 vaccination as immigration control tool (BBC, September 2021).

The lack of global solidarity and unfair distribution of vaccines and other medicines across the world is nothing surprising. The cries for making vaccines a public good that should be subject to humanitarian principles sound reasonable but at the same time they are just empty words. At the World Health Assembly, before the vaccines had been produced, a steady stream of heads of state - including China's President Xi, Germany's Chancellor Merkel, and France's President Macron - called for any Covid-19 vaccine to be treated as a global public good and made widely and quickly available worldwide (Moon 2020). The media reported on 
"Europe's vaccine solidarity boost" after some countries' decisions to block vaccine exports outside the European Union "if that's what is needed to enforce the bloc's own contracts with drugs manufacturers". Of course, Europe in this context means the European Union, which is geopolitical verbal acrobatics with specific goals.

In addition to the tragic record of the Covid-19 pandemic, rich countries and benefactors have had a huge number of occasions to save lives from hunger, lack of drinking water, curable diseases, etc. At the beginning of the pandemic, Arundhati Roy hoped for a radical change and a "new portal" for a better world. A year later her words are just proof of failed hopes. The injustice is deeply embedded, both nationally and internationally, in the political, economic, and societal structures - the world's foundations lie on structural injustice, and the Covid-19 pandemic has mostly affected the poorest layers of society. People have been discriminated against on various grounds, but the Covid-19 pandemic has proven once again that class differentiation is the deepest and the most important line of differentiation between worthy and expendable lives within and between societies.

\section{Instead of Conclusion: Nanny States, New Authoritarianism and Vaccine Conditioned Freedoms}

The future of coronavirus vaccines production is secured, at least from the perspective of the research labs, producers, and corporations. Their eventual availability may alleviate the health emergency but it will take much time and a lot of casualties before any significant result is achieved. By dealing with Covid-19 patients, all the others have already been sacrificed and seen as non-urgent and less important. In their selfishness, presented as care for national security and sovereignty, the states and blocks turn a blind eye to the fact that the world is still deeply connected, despite all the talks about slowbalization (as an opposite to globalization). For instance, the dramatic situation in Brazil has been securitized by the scientists and media as a global security threat (Guardian, 3 March 2021).

As seen from a geopolitical perspective, vaccine production and distribution is just a continuation of the geopolitical clash with different means (but the same goal) - to paraphrase Clausewitz. There is open war-like rhetoric between the great powers, i.e. the West and the Rest, regarding the vaccines. For instance, Wall Street Journal (6 March 2021) quoted a US official blaming the Russian, Chinese, and Iranian sides for an alleged crime against humanity due to their claims that the vaccines they produce are more efficient, less expensive, and more affordable than the Western ones. At the same time, the Western media outlets and officials disregard the same findings published in highly esteemed academic journals such as Lancet (Logunov et al, 2021). Yet the geopolitics of the pandemic and vaccines (just like the geopolitics of energy supplies) have shown the deep cracks within and among societies and states, which is consistent with the hybrid international system. For instance, Italy banned the export of vaccines to its Western ally Australia, while at the same time signing a deal for the production of the Russian vaccine (as the first EU country to do so). The struggle between biopolitics and geopolitics may give a strange picture of today's world and its future. The Balkan states (with the exception of Serbia) are paralyzed, while the population laments its bad fortune as expressed in an old movie's line "The East has written us off, while the West has not embraced us yet". 
On the other hand, the race in vaccine production is accompanied by "vaccine hesitancy" and numerous conspiracy theories, even in highly developed countries. Yuval Harari explains that truth is painful and complicated, and when it comes to the virus as such it is a highly complex matter for the majority of citizens to understand (YouTube, 9 November 2020). It is much easier to think that there is a group of billionaires who invented this thing in order to make more profit or take over the world. The scientists do not speak the language most people understand, while the politicians trying to use and hide behind the scientists' authority and knowledge, usually speak nonsense and undertake contradictory measures with no scientific rationale. The people, the story-telling animals as Harari dubs them, need an understandable narrative and reasonable explanation of the proposed measures. Yet this is also the price that is paid for the long-term distrust in politics and politicians, who are now in a sort of a coalition with the expert/health commissions. It is not only unhelpful for the political elites but is harmful to the scientific teams too.

The same applies to vaccines' application. Through a survey that encompassed five countries (UK, USA, Ireland, Mexico, and Spain) a research study found that certain conspiracy theories have taken root in significant portions of the population. They had predicted "vaccine hesitancy" even before any vaccine was produced (Roozenbeek Jon et al, 2020). Prior surveys concluded that there is an association between self-reported minority status and belief in conspiracy theories. Van Prooijen and his associates (2018) argue that "feelings of deprivation lead marginalized minority members to perceive the social and political system as rigged, stimulating belief in both identity relevant and irrelevant conspiracy theories". One should also take into account several important motivational drivers as predictors of belief in misinformation: lower trust in science and scientists, lower trust in journalists and the mainstream media, lower trust in government, etc. The media report of two prominent French doctors has triggered a storm of criticism after they discussed the idea of testing a vaccine for coronavirus in Africa as early as April 2020 (France 24, 3 April 2020).

In the meantime, the EU is pushing for new walls between its block and the others but also among the member-states' population through the vaccine passports and movement restrictions. It is still an issue that divides the member states, with Greece that unveiled a digital vaccination certificate in February 2021 for those who have received two doses of the vaccine and other countries that are currently issuing or asking for vaccine certificates (such as the Czech Republic, Poland, Italy, Spain, and Portugal). Yet some countries, including France and Germany, have expressed concern that easing travel for people who have been inoculated would discriminate against others who are still waiting. The issue of vaccination is now transforming into a human rights issue: on one hand, it is a matter of equal access, while on the other it tackles personal freedom vis-à-vis nanny statism. Most of the countries have promised that Covid-19 vaccines would not be mandatory but obviously they may turn into a matter of discrimination and even stigmatization between the ones who would get vaccinated and the others who would be labeled as conspiracy theorists. It is still early to say how the battle between individual freedoms and collective (public) good will end.

Given the debate over the duration of any Covid-19 antibodies, it is unclear exactly how often people are going to have to be vaccinated, how many mutations the virus may have got, etc. Obviously, the ideal solution would be an invention of an anti-viral cure rather than a vaccine, but some believe that vaccines are not only more profitable but also possess disciplining power. The very fact that it is still early and there is an obvious lack of solid 
empirical research about the protective force of the vaccines (let alone propaganda over the (in)efficiency and quality among the different brands), vaccination bears the power of both securitization and gaslighting, depending on elites' preferences (Vankovska, 2020).

The outcome of the two conjoining tendencies of biopolitics and privatization of medical care reveals a grim picture: the private/corporate interest is prevailing over the vaccine production and distribution, while the State succumbs to authoritarianism. In a world of rising techno-feudalism, the apparent upswing of State is not only a misleadingly positive sign but even a worrisome indication that the post-corona world may combine the worst from the State and the worst from corporate capitalism. In the world that had already engulfed the wave of new authoritarianism (Fouskas and Gökay 2019) with its intra- and inter-imperial shifts and faultlines, it seems very reasonable to assume that once freedom is taken away, it's rarely ever restored. That is particularly true when the populace has grown resigned, complacent, or indifferent. The Covid-19 vaccine passports or territorial green passes could very well lead to more impositions that hijack personal autonomy. Such citizens are unable to change their own societies, let alone change international relations that lead towards a disastrous future for humanity.

\section{References}

Abdoli Amir, "Iran, sanctions, and the COVID-19 crisis", Journal of Medical Economics, vol. 23, no. 12, 2020.

Al Jazeera, "Yanis Varoufakis: Capitalism has become 'techno-feudalism"', 19 February 2021, online https://www.aljazeera.com/program/upfront/2021/2/19/yanis-varoufakis-capitalismhas-become-techno .

Amundi Research Center, "Geopolitics of Vaccines", 5 May 2021, online https://researchcenter.amundi.com/article/geopolitics-vaccine.

Anadoly Agency, "Russian COVID-19 vaccine to be produced in Italy", 9 March 2021, online https://www.aa.com.tr/en/latest-on-coronavirus-outbreak/russian-covid-19-vaccine-to-beproduced-in-italy/2169317.

Balkan Insight, "Work Starts in Serbia on Chinese Sinopharm Vaccines Factory", 9 September 2021, online https://balkaninsight.com/2021/09/09/work-starts-in-serbia-on-chinesesinopharm-vaccines-factory/.

BBC News, "Trump Says Coronavirus Worse 'Attack' than Pearl Harbor", 7 May 2020, online https://www.bbc.com/news/world-us-canada-52568405.

BBC News, "Ghana President Nana Akufo-Addo to UN - 'Stop dey use Covid-19 vaccination as immigration control against Africans'", 23 September 2021, online https://www.bbc.com/ pidgin/tori-58661993.

Bloomberg, "Vaccines Turn Into Geopolitics in Europe's Most Volatile Region", 22 January 
2021, online https://www.bloomberg.com/news/articles/2021-01-22/vaccines-turn-intogeopolitics-in-europe-s-most-volatile-region.

Boyle A. Francis, "SARS-cov-2 is a biological warfare weapon", Security Dialogues, vol. 11, no. 2, 2020.

Buka, "Turković: Vakcinekoje je donioVučićkoriste se u siromašnimzemljama" [Turković: Vaccines delivered by Vučić are used in poor countries], 2 March 2021, online https://www.6yka.com/ novosti/turkovic-vakcine-koje-je-donio-vucic-koriste-se-u-siromasnim-zemljama.

CHOICE, "Voice for CHOICE Regional Roundtable: Assessing 17+1 Fallout, Vaccine Diplomacy, and More", 18 February 2021, online https://chinaobservers.eu/voicefor-choice-regional-round table-assessing-171-fallout-vaccine-diplomacy-andmore/?fbclid=IwAR16dPmzXsmScZWwf-fjVNjKLHAI3iNcxb7QIQJQ5wYULRerQ-YOqZqJNLI.

Deutsche Welle, "Russia's Putin claims victory in global coronavirus vaccine race", 11 August 2020, online https://www.dw.com/en/russias-putin-claims-victory-in-global-coronavirusvaccine-race/a-54524385.

Deutsche Welle, "The politics of unproven cures", 15 July 2020, online https://www.dw.com/ en/opinion-the-politics-of-unproven-cures/a-54130076.

Dnevnik.hr, "Intervju s Milanovićem", 18 February 2021, online https://dnevnik.hr/vijesti/ hrvatska/gost-dnevnika-nove-tv-predsjednik-zoran-milanovic---640704.html.

Euractiv, "Serbia launches production of Russian vaccine", 7 June 2021, online https://www. euractiv.com/section/politics/short news/serbia-launches-production-of-russian-vaccine/.

Fouskas K. Vassilis and Shampa Roy-Mukherjee, "Neo-liberalism and Ordoliberalism - One or Two Critiques? An Introduction", Critical Sociology, vol. 45, no. 7-8, 2019.

Fouskas K. Vassilis and BülentCökay, The Disintegration of Euro-Atlantacism and New Authorianism, London: Palgrave Macmillan, 2019.

France 24, "EU to propose Covid-19 vaccine passports in March", 1 March 2021, online https:// www.france24.com/en/europe/20210301-eu-to-propose-covid-19-vaccine-passports-inmarch.

France 24, "'Not guinea pigs': Africa vaccine trial suggestion sparks uproar", 3 April 2020, online https://www.france24.com/en/20200403-not-guinea-pigs-africa-vaccine-trialsuggestion-sparks-uproar.

France 24, "France, EU back Italy's decision to block Covid-19 vaccine shipment to Australia", 4 March 2021, online https://www.france24.com/en/health/20210305-france-eu-back-italys-decision-to-block-covid-19-vaccine-shipment-to-australia. 
France 24, "Le Covid-19 pousse la France à relocaliser son industriepharmaceutique", 13 May 2020, online https://www.france24.com/fr/20200513-le-covid-19-pousse-la-france$\%$ C3\%A0-relocaliser-son-industrie-pharmaceutique.

Guardian, "Brazil's Covid outbreak is global threat that opens door to lethal variants scientist", 3 March 2021, online https://www.theguardian.com/world/2021/mar/03/brazilcovid-global-threat-new-more-lethal-variants-miguel-nicolelis.

Independent, "Dutch King Willem-Alexander declares the end of the welfare state", 17 September 2013, online: https://www.independent.co.uk/news/world/europe/dutch-kingwillem-alexander-declares-end-welfare-state-8822421.html.

Intellinews, "Serbia to become vaccine production hub for the Western Balkans", 17 February 2021, online https://intellinews.com/serbia-to-become-vaccine-production-hub-for-thewestern-balkans-203135/ .

KegleyCharls and Blanton Shannon, World Politics: Trend and Transformation, Cengage Learning Press, 2012.

Kirkova, Rina, "The Second Global Bipolarity or Bi-Multipolarity", Security Dialogues, vol. 6, no. 1 (doi: $10.47054 /$ SD152.10351k).

Logunov et al, "Safety and efficacy of a rAd26 and rAd5 vector-based heterologous primeboost COVID-19 vaccine: an interim analysis of a randomised controlled phase 3 trial in Russia", The Lancet, vol. 397, no. 10275, 20 February, 2021.

Moon Suerie, "The vaccine race: will public health prevail over geopolitics?", In: GlobalChallenges, Graduate Institute of International and Development Studies, Special Issue 1(2020).

NATO 2030: United for a New Era 2020, online https://www.nato.int/nato_static_fl2014/ assets/pdf/2020/12/pdf/201201-Reflection-Group-Final-Report-Uni.pdf.

Newsletter for the EU (NEU), "Vaccines and geopolitical implication of Covid-19 crisis", 9 January 2021, online http://www.newslettereuropean.eu/vaccines-geopolitical-implication-covid-19crisis/.

New York Times, "In Vaccine Geopolitics, a Great Game Played With Ukrainians' Health", 9 January 2021, online https://www.nytimes.com/2021/01/09/world/europe/covid-vaccinesukraine.html?.

Novinite, "Bulgarian Parliament Says No to Russian Vaccine", 5 March 2021, online https:// www.novinite.com/articles/208324/Bulgarian+Parliament+Says+No+to+Russian+Vaccine.

Oxfam, "Mega-rich recoup COVID-losses in record-time yet billions will live in poverty for at least a decade", 25 February 2021, online https://www.oxfam.org/en/press-releases/mega- 
rich-recoup-covid-losses-record-time-yet-billions-will-live-poverty-least.

Our World in Data, "Statistics and Research. Coronavirus (COVID-19) Vaccinations 2021", online https://ourworldindata.org/covid-vaccinations.

Pilling David, "Any Covid-19 vaccine must be treated as a global public good", The Financial Times, 13 May 2020, online https://www.ft.com/content/cf0df38a-9500-11ea-af4b-499244625ac4 .

Politico, "The ultimate geopolitical game - distributing a coronavirus vaccine", 27 July 2020, online https://www.politico.eu/article/the-ultimate-geopolitical-game-distributing-acoronavirus-vaccine/.

Precision Vaccinations, "Belarus Launches Sputnik V Vaccine Production", 27 February 2021, online https://www.precisionvaccinations.com/2021/02/27/belarus-launches-sputnik-vvaccine-production.

Radio Free Europe (RFE), "China's Strategic Vaccine Diplomacy Gains a Foothold In The Balkans", 16 February 2021, online https://www.rferl.org/a/china-strategic-vaccine-diplomacy-gainsa-foothold-in-the-balkans/31106320.html.

Republika, "Instead of vaccines the country will get rifles", 1 March 2021, online https:// english.republika.mk/news/macedonia/instead-of-vaccines-the-country-will-get-rifles/.

Roozenbeek Jon et al, "Susceptibility to misinformation about COVID-19 around the world", Royal Society Open Science, vol. 7, no. 2011992020, online https://royalsocietypublishing.org/ doi/pdf/10.1098/rsos.201199.

СДК, "САД и НАТО разбираатдекаморамедакупимевакциниодКина, речеЗаев“ [Zaev: USA and NATO understand that we had to purchase vaccines from China], 3 February 2021, online https://sdk.mk/index.php/makedonija/sad-i-nato-razbiraat-deka-morame-da-kupimevaktsini-od-kina-reche-zaev/.

Sharma Ruchir, "The Rescues Ruining Capitalism", The Wall Street Journal, 24 July 2020, online https://www.wsj.com/articles/the-rescues-ruining-capitalism-11595603720.

TASS, "Belarus works on launching full production cycle of Russian Sputnik V - Kremlin", 9 September 2021, online https://tass.com/society/1335887.

Terranova Ciuseppe, "Geopolitics of Covid-19: global challenge at national borders", AIMS Geosciences, vol. 6, no. 4, 2020.

Umbach Frank, "Multipolaritätgestalten?", Berlin: KAS, 2006, online https://www.kas.de/de/ web/auslandsinformationen/artikel/detail/-/content/multipolaritaet-gestalten-1.

Van Prooijen et al., "Increased conspiracy beliefs among ethnic and Muslim minorities", Applied 
Cognitive Psychology, vol. 32, no. 5, 2018.

Vankovska Biljana, The Membership to NATO: On the Frontline?, Skopje: Faculty of Philosophy, 2020.

Vankovska Biljana, "Dealing with COVID-19 in the European periphery: between securitization and 'gaslighting' ", Journal of Global Faultlines, vol. 7, no. 1, June-August 2020.

Viorel Mionel, SilviuNeguț\&OanaMionel, "Pandemopolitics: How a public health problem become a geopolitical and geoeconomic issue", Eurasian Geography and Economics, vol. 61, no. $4-5,2020$.

Wall Street Journal, "Russian Disinformation Campaign Aims to Undermine Confidence in Pfizer, Other Covid-19 Vaccines, U.S. Officials Say", 6 March 2021.

WHO Newsroom, "Coronavirus disease (COVID-19): Vaccine access and allocation", 28 October 2020, online https://www.who.int/news-room/q-a-detail/coronavirus-disease-(covid-19)vaccine-access-and-allocation?adgroupsurvey $=\{$ adgroupsurvey $\}$ \&clid $=C$ jwKCAiAp4KCBhB6 EiwAxRxbpFI6Fj-HMF9J6bT75xo_6roLtvvRVKA0vmxRilD0mTWWN5k5ENErGxoC8TMQAvD_ BwE .

WHO Guidance Document, "Status of COVID-19 Vaccines within WHO EUL/PQ evaluation process", 29 September 2021, online https://extranet.who.int/pqweb/sites/default/files/ documents/Status COVID VAX 29Sept2021.pdf.

Xinhua, "Belarus, China in talks on joint COVID-19 vaccine production: media", 27 July 2021, online http://www.xinhuanet.com/english/europe/2021-07/27/c 1310089967.htm.

YouTube, "Yuval Noah Harari Explains the Popularity of COVID Conspiracies", 9 November 2020, online https://www.youtube.com/watch?v=HguDz95yAsQ . 